Original Article

\title{
Exogenous application of salicylic acid induces salinity tolerance in eggplant seedlings
}

\author{
Aplicação exógena de ácido salicílico induz tolerância à salinidade em mudas de \\ berinjela
}

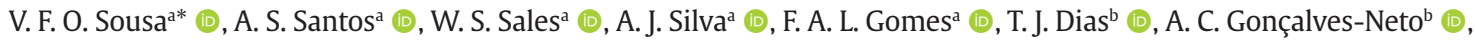

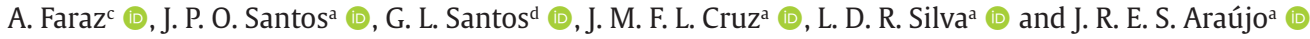

aUniversidade Federal da Paraíba-UFPB, Centro de Ciências Agrárias, Departamento de Ciências Agrárias e Ambientais, Areia, PB, Brasil 'Universidade Federal da Paraíba-UFPB, Centro de Ciências Humanas, Sociais e Agrárias, Departamento de Agricultura, Bananeiras, PB, Brasil 'Glocal University-GU, School of Life and Allied Health Sciences, Departament Life Sciences, Saharanpur, UP, Índia

dUniversidade Federal Rural do Semi-Árido-UFERSA, Centro de Ciências Agrárias, Departamento de Ciências Agronômicas e Florestais, Mossoró, RN, Brasil
\end{abstract}

\begin{abstract}
Under salt stress conditions, plant growth is reduced due to osmotic, nutritional and oxidative imbalance. However, salicylic acid acts in the mitigation of this abiotic stress by promoting an increase in growth, photosynthesis, nitrogen metabolism, synthesis of osmoregulators and antioxidant enzymes. In this context, the objective was to evaluate the effect of salicylic acid doses on the growth and physiological changes of eggplant seedlings under salt stress. The experiment was conducted in a greenhouse, where the treatments were distributed in randomized blocks using a central composite matrix Box with five levels of electrical conductivity of irrigation water (CEw) $(0.50 ; 1.08$; 2.50; 3.92 and $\left.4.50 \mathrm{dS} \mathrm{m}^{-1}\right)$, associated with five doses of salicylic acid (SA) $(0.00 ; 0.22 ; 0.75 ; 1.28$ and $1.50 \mathrm{mM})$, with four repetitions and each plot composed of three plants. At 40 days after sowing, plant height, stem diameter, number of leaves, leaf area, electrolyte leakage, relative water content, and total dry mass were determined. ECW and SA application influenced the growth and physiological changes of eggplant seedlings. Increasing the $\mathrm{ECW}$ reduced growth in the absence of SA. Membrane damage with the use of SA remained stable up to $3.9 \mathrm{dS} \mathrm{m}^{-1}$ of ECW. The relative water content independent of the CEw increased with $1.0 \mathrm{mM}$ of SA. The use of SA at the concentration of $1.0 \mathrm{mM}$ mitigated the deleterious effect of salinity on seedling growth up to $2.50 \mathrm{dS} \mathrm{m}^{-1} \mathrm{of} \mathrm{ECW}$.
\end{abstract}

Keywords: Solanum melongena L., salinity the water, phytohormone, stress signal.

\begin{abstract}
Resumo
Em condições de estresse salino, o crescimento das plantas é reduzido, em virtude, do desequilíbrio osmótico, nutricional e oxidativo. Contudo, o ácido salicílico atua na mitigação desse estresse abiótico por promover incremento no crescimento, fotossíntese, metabolismo do nitrogênio, síntese de osmorreguladores e enzimas antioxidantes. Nesse contexto, objetivou-se avaliar o efeito de doses de ácido salicílico sobre o crescimento e alterações fisiológicas de mudas de berinjela sob estresse salino. 0 experimento foi conduzido em casa de vegetação, onde os tratamentos foram distribuídos em blocos ao acaso utilizando uma matriz composta central Box com cinco níveis de condutividade elétrica da água de irrigação (CEa) $\left(0,50 ; 1,08 ; 2,50 ; 3,92\right.$ e 4,50 dS m$~^{-1}$ ), associada a cinco doses de ácido salicílico (AS) $(0,00 ; 0,22 ; 0,75 ; 1,28$ e 1,50 mM), com quatro repetições e cada parcela composta por três plantas. Aos 40 dias após a semeadura, foram determinados a altura da planta, diâmetro do caule, número de folhas, área foliar, vazamento de eletrólito, teor relativo de água e massa seca total. A CEa e a aplicação de AS influenciaram no crescimento e nas alterações fisiológicas das mudas de berinjela. O aumento da CEa reduziu o crescimento na ausência de AS. O dano de membrana com o uso de AS manteve-se estável até 3,9 dS m-1 de CEa. $O$ conteúdo relativo de água independentemente da CEa aumentou com $1 \mathrm{mM}$ de SA. O uso de AS na concentração de $1 \mathrm{mM}$ mitigou o efeito deletério da salinidade no crescimento das mudas até $2,50 \mathrm{dS} \mathrm{m}^{-1} \mathrm{de}$ CEa.
\end{abstract}

Palavras-chave: Solanum melongena L., salinidade da água, fitohormônio, sinalização de estresse.

\section{Introduction}

Eggplant (Solanum melongena L.) acts in a preventive and therapeutic way of diabetes and cardiovascular problems, due to being rich in antioxidants, with this, it

assumes agricultural prominence along with other species of the solanaceous family, and presents a high expansion of cultivated area in the world (Kwon et al., 2008).

*e-mail: valeriafernandesbds@gmail.com

Received: October 27, 2021 - Accepted: December 28, 2021 
In the olive sector, the production of seedlings is the most important phase of the crop cycle, as it reflects on performance in the field and consequently on production (Balliu et al., 2017). However, factors such as climatic conditions, type of substrate and water used for irrigation affect the quality of eggplant seedlings (Meneghelli et al., 2017; Almeida et al., 2019).

Salinity in irrigation water is a limiting factor for germination, seedling development and productivity of various crops, especially in arid and semi-arid regions (Munns and Tester, 2008). Because it causes ionic imbalance and consequent toxicity, in addition to favoring oxidative stress, physiological drought and nutrient deficiency in the plant, salinity compromises morphological and physiological yields (Zörb et al., 2019). Under conditions of tolerance to salt stress, plants tend to reduce reactive oxygen species, maintaining physiological and biochemical processes, as well as plant growth and production, thus avoiding enzyme inactivation, lack of nutrients, ionic toxicity in tissues and, consequently, cell death (Fernandes et al., 2022).

In eggplant culture, the unitary increase in the electrical conductivity of irrigation water above $0.5 \mathrm{dS} \mathrm{m}^{-1}$ led to a 13.5\% reduction in fruit productivity (Lima et al., 2015). Likewise, Santos et al. (2018) observed that the yield of eggplant fruits decreased with the increase in salinity. Therefore, agricultural production alternatives must be sought to meet the demand for food, mitigating the harmful effects of salinity.

Salicylic acid (SA) acts as a signaling mechanism for adjusting various abiotic stresses (Jayakannan et al., 2015). SA has a high biostimulatory capacity for salinity tolerance, by stimulating positive regulation of the ascorbateglutathione pathway (AsA-GSH), increasing tolerance under ion toxicity and oxidative stress, preventing the sudden drop in plant growth (Asensi-Fabado and MunnéBosch, 2011; Hasanuzzaman et al., 2019; Kaya et al., 2020). In addition, SA increases the accumulation of osmoprotectors, improving turgence in plant cells under stress and antioxidant enzyme activation (Dutra et al., 2017; Costa et al., 2022). Several studies have shown the attenuating effect of salt stress with the application of SA in fruit vegetables, such as bell peppers (Amirinejad et al., 2017; Kaya et al., 2020), pumpkin (Rafique et al., 2011) and tomatoes (Mimouni et al., 2016).

However, there is variation of this effect in species, forms of application and concentration of SA and cultivation conditions. In the study by Ribeiro et al. (2020), when evaluating morphophysiological aspects of watermelon as a function of salinity in water and exogenous application of SA, found that the acid did not mitigate the deleterious effect of salinity, however, it beneficially increased the morphophysiology of plants up to a dosage of $0.85 \mathrm{mM}$. However, Rafique et al. (2011), in the cultivation of pumpkin seedlings, when soaking the seed with SA, observed that the protein content and activities of the protease and nitrate reductase enzymes were significantly influenced with concentrations of $30 \mathrm{mg} \mathrm{L}^{-1}$ of SA and that the soaking of the seed mitigates the adverse effects of salt stress on the initial growth of pumpkin.
Thus, based on the hypothesis that salicylic acid can mitigate the damage caused by salt stress, due to the increase in plant growth, synthesis of osmoregulators and plant antioxidant system, the objective was to evaluate the effect of salicylic acid on growth and physiological changes of eggplant seedlings irrigated with saline water, the objective was to evaluate the effect of salicylic acid on growth and physiological changes of eggplant seedlings irrigated with water different electrical conductivities.

\section{Material and Methods}

The experiment was conducted in a protected environment (greenhouse) between October and December 2019, in the experimental area of the Department of Phytotechnics at the Center for Agricultural Sciences, Federal University of Paraiba, Campus II, in Areia-PB. The average temperature inside the greenhouse was $29.42{ }^{\circ} \mathrm{C}$ and the average relative humidity was $63.15 \%$.

Treatments were distributed in randomized blocks using Box's central composite matrix (Tekindal et al., 2014), combining electrical conductivity of irrigation water (EC) with concentrations of salicylic acid (SA). The minimum $(-\alpha)$ and maximum $(\alpha)$ values ranged, respectively, from 0.5 to $4.5 \mathrm{dS} \mathrm{m}^{-1}$ and 0.0 to $1.5 \mathrm{mM}$, totaling 9 treatments (Table 1), with four replicates, making up 36 experimental plots, each plot consisting of three plants. Salicylic acid concentrations were based on previous experiments with other vegetables (Silva et al., 2019; Ribeiro et al., 2020). The electrical conductivities in the irrigation water were based on the threshold salinity of the crop (Dias et al., 2016).

The different saline waters were prepared by adding different concentrations of salts to water $\left(0.5 \mathrm{dS} \mathrm{m}^{-1}\right)$, namely sodium chloride $(\mathrm{NaCl})$, calcium chloride $\left(\mathrm{CaCl}_{2} \cdot 2 \mathrm{H}_{2} \mathrm{O}\right)$, and magnesium chloride $\left(\mathrm{MgCl}_{2} \cdot 6 \mathrm{H}_{2} \mathrm{O}\right)$, in the proportion $7: 2: 1$, respectively, this relation is predominant in the main sources of water available for irrigation in the Northeast Brazillian (Medeiros, 1992). Obeying the relationship between ECW and the concentration of salts $\left(\right.$ mmol $_{c} L^{-1}=$ CE x 10), (Rhoades et al., 1992). After being

Table 1. Combinations (treatments) are generated through the Box central composite matrix.

\begin{tabular}{cccccc}
\hline \multicolumn{2}{c}{ Levels } & & & \multicolumn{2}{c}{ Doses } \\
\cline { 1 - 2 } \cline { 5 - 5 } ECw & SA & & Ecw & SA \\
\hline-1 & -1 & & 1.08 & 0.22 \\
-1 & 1 & & 1.08 & 1.28 \\
1 & -1 & & 3.92 & 0.22 \\
1 & 1 & & 3.92 & 1.28 \\
$-\alpha$ & 0 & & 0.50 & 0.75 \\
$\alpha$ & 0 & & 4.50 & 0.75 \\
0 & $\alpha$ & & 2.50 & 1.50 \\
0 & $-\alpha$ & & 2.50 & 0.00 \\
0 & 0 & & 2.50 & 0.75 \\
\hline
\end{tabular}

$\mathrm{ECW}=$ Electrical Conductivity of Irrigation Water; $\mathrm{SA}=$ Salicylic acid. 
prepared, the saline water was stored in plastic buckets with a capacity of $60 \mathrm{dm}^{3}$. The weekly ECw check was performed with the aid of a portable conductivity meter (model CD-860, Instrutherm, USA).

Before sowing, the seeds were soaked in the respective solutions of SA for each treatment for 8 hours (Nóbrega et al., 2020). Eggplant seeds, cultivar Preta Comprida from ISLA ${ }^{\circledast}$, at a depth of $0.5 \mathrm{~cm}$, were used in the sowing in polypropylene plastic bags with the following dimensions $25 \mathrm{~cm}$ in height and $13 \mathrm{~cm}$ in diameter and with a capacity of $1,230 \mathrm{dm}^{3}$. At 10 days after sowing (DAS), thinning was performed, leaving one plantlet per bag. The bags were previously filled with soil classified as Oxisol (Embrapa, 2006) and tanned bovine manure in a 1:1 ratio. The soil was collected at a depth of $0-20 \mathrm{~cm}$ (horizon A) and then it was removed and sieved. Chemical analysis (Table 2) and salinity (Table 3 ) of the substrate used was performed.

After thinning, SA solutions for foliar application were prepared with distilled water and $0.05 \%$ Tween 80 was added to the solution, as a surfactant to improve the absorption effect, the absence of SA treatment was prepared with distilled water and Tween 80 (Silva et al., 2019). The eggplant seedlings were sprayed, with SA solutions, with the aid of the manual sprayer (model B07V9W8FLG, Importway), so that they are completely wet, with weekly applications, totaling five applications, according to Silva et al. (2019), care was taken not to interfere when applying the SA solutions in the respective treatments. The Irrigation with saline water were performed daily, with the volume of water applied using the drainage lysimetry method (Bernardo et al., 2006).

Eggplant seedlings were harvested 40 DAS, when the seedlings were ready for transplanting, to assess the parameters:
Plant height: measured between the neck of the plant and the bud located at the tip of the apex, through a measuring tape graduated in centimeters.

Stem diameter: determined from the ground level, on the plant's neck, with the aid of a digital caliper, and the results expressed in millimeters.

Number of leaves: quantified from the first leaf at the bottom, up to the apical meristem. For that, only those that presented the fully expanded limbus were considered.

Leaf area: determined by measuring the length $(\mathrm{L})$ and width (W) of all plant leaves according to Equation 1 by Hinnah et al. (2014):

$$
L A=0.4395 L W^{1.0055}
$$

Relative water content (\%): ten leaf discs of $10 \mathrm{~mm}$ diameter were collected and the determination of fresh mass (FM) was made on a semi-analytical scale. Then, the parts were incubated in distilled water for $4 \mathrm{~h}$ and the turgid mass (TM) measured. Finally, the parts were dried in an oven at $70{ }^{\circ} \mathrm{C}$ for $48 \mathrm{~h}$ and the dry mass (DM) was determined. The relative water content (RWC) was calculated according to Equation 2 (Irigoyen et al., 1992):

$$
R W C=\frac{(F M-D M)}{(T M-D M)} * 100
$$

Electrolyte leakage: The integrity of the membranes was estimated by electrolyte leakage (EL) (Lutts et al., 1996). Ten leaf discs of $10 \mathrm{~mm}$ in diameter were collected from leaves of one plant from each plot and placed in Becker with $40 \mathrm{dm}^{3}$ of distilled water and left to rest at $25^{\circ} \mathrm{C}$ for 4 hours. The electrical conductivity of the solutions (L1) was read and the Beckers containing the disks were placed closed with aluminum foil in an oven for 2 hours at $90^{\circ} \mathrm{C}$. The electrical conductivity was read again (L2). Membrane

\begin{tabular}{|c|c|c|c|c|c|c|c|c|c|c|c|}
\hline \multirow{2}{*}{ pH } & $\mathbf{P}$ & $\mathbf{K}^{+}$ & $\mathrm{Na}^{+}$ & $\begin{array}{c}\mathbf{H}^{+} \\
+\mathrm{Al}^{+3}\end{array}$ & $\mathrm{Al}^{+3}$ & $\mathrm{Ca}^{+2}$ & $\mathbf{M g}^{+2}$ & SB & TCE & V (\%) & O.M. \\
\hline & \multicolumn{2}{|c|}{-- mg dm ${ }^{-3}$-- } & \multicolumn{7}{|c|}{ 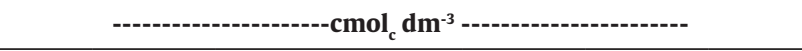 } & \multicolumn{2}{|c|}{$\mathrm{g} \mathrm{dm}^{-3}$} \\
\hline 6.7 & 11.37 & 84.89 & 0.23 & 1.55 & 0.0 & 4.51 & 0.37 & 7.30 & 8.55 & 82.45 & 22.07 \\
\hline
\end{tabular}

Table 2. Chemical analysis of the substrate.

$\mathrm{pH}=$ hydrogenionic potential; $\mathrm{P}=$ phosphorus; $\mathrm{K}^{+}=$Potassium; $\mathrm{Na}^{+}=$Sodium; $\mathrm{H}^{+}=$Hydrogen; $\mathrm{Al}^{+3}=$ Aluminum; $\mathrm{Ca}^{+2}=$ Calcium; $\mathrm{Mg}^{+2}=\mathrm{Magnesium}$; $\mathrm{SB}=$ Sum of Bases; TCE = Total Cation Exchange Capacity; V = Base Saturation; O.M. = Organic Matter.

\begin{tabular}{|c|c|c|c|c|c|c|c|c|c|c|c|}
\hline \multirow{2}{*}{$\begin{array}{c}\text { ECw } \\
d S \mathbf{m}^{-1}\end{array}$} & \multirow{2}{*}{$\mathrm{pH}$} & \multirow{2}{*}{$\frac{E C}{\text { dS }^{-1}}$} & \multirow{2}{*}{$\frac{\mathrm{SO}_{4}^{-2}}{\mathrm{mg} \mathrm{L}^{-1}}$} & $\mathbf{K}$ & $\mathrm{Na}$ & $\mathrm{Ca}+\mathrm{Mg}$ & $\mathrm{CO}_{3}^{-2}$ & $\mathrm{HCO}_{3}^{-}$ & Cl- & RAS & \multirow{2}{*}{$\begin{array}{r}\text { ESP } \\
\%\end{array}$} \\
\hline & & & & \multicolumn{7}{|c|}{ - } & \\
\hline IS & 7.2 & 0.6 & 0.30 & 0.5 & 3.3 & 7.3 & 0.0 & 29.5 & 20.0 & 1.3 & 0.7 \\
\hline 0.50 & 6.7 & 3.7 & 171.0 & 2.5 & 3.9 & 9.0 & 0.0 & 0.0 & 10.0 & 6.0 & 10.2 \\
\hline 1.08 & 6.5 & 4.1 & 95.1 & 2.8 & 20.7 & 12.3 & 0.0 & 5.0 & 60.0 & 11.2 & 13.4 \\
\hline 2.50 & 5.5 & 5.3 & 134.5 & 1.9 & 19.2 & 8.0 & 0.0 & 0.0 & 50.0 & 9.6 & 11.4 \\
\hline 3.92 & 5.8 & 4.1 & 150.0 & 2.5 & 13.3 & 9.2 & 0.0 & 5.0 & 15.0 & 6.2 & 7.4 \\
\hline 4.50 & 5.9 & 5.7 & 145.3 & 3.3 & 61.1 & 16.0 & 0.0 & 5.0 & 90.0 & 20.8 & 22.7 \\
\hline
\end{tabular}

Table 3. Saline analysis of the substrate at the beginning and end of the experiment.

$\mathrm{ECW}=$ Electrical conductivity of water; $\mathrm{pH}=$ hydrogenionic potential; $\mathrm{EC}=$ Electric conductivity; IS = initial substrate; SAR = Sodium adsorption ratio; ESP = Exchangeable Sodium Percentage. 
damage, estimated by the percentage of electrolyte leakage, was estimated by Equation 3:

$$
E L=\left(\frac{L 1}{L 2}\right) * 100
$$

Total dry mass (g): All plant material was collected and submitted to drying in an oven with forced air circulation at $65^{\circ} \mathrm{C}$, until constant mass.

Data were analyzed for normality by the Shapiro-Wilk test and homogeneity of variances by the Bartlett test and then submitted to analysis of variance by the F test $(p<0.05$ ) and regression analysis for salicylic acid concentrations and electrical conductivity of irrigation water using the $\mathrm{R}$ plataform using the e ExpDes.pt packages (Ferreira et al., 2018). The response surface graphs were made using the SigmaPlot ${ }^{\circledR}, 12.5$ version software (Systat Software, San Jose, CA, EUA).

\section{Results and Discussion}

There was a significant interaction for all variables analyzed, except the stem diameter, demonstrating that both factors, electrical conductivity of irrigation water (ECw) and application of SA interfere simultaneously in the growth of eggplant seedlings. Therefore, salicylic acid acts in the morphophysiological regulation of eggplant under salt stress conditions (Raghami et al., 2016).

The height of the eggplant seedlings, with the addition of ECW and without SA application, decreased from 8.14 to $7.39 \mathrm{~cm}$ between 0.5 and $4.5 \mathrm{dS} \mathrm{m}^{-1}$. While, with the application of SA in the ECw 0.5 and $1.1 \mathrm{dS} \mathrm{m}^{-1}$, the height increased in a linearly, with increments of 54.25 and $39.29 \%$, respectively, between 0 and $1.5 \mathrm{mM}$ of SA. At the same time, the seedlings irrigated with water of $2.5 \mathrm{dS} \mathrm{m}^{-1}$ showed a quadratic effect with an increase to a concentration of $1.2 \mathrm{mM}$ of acid, they showed $8.56 \mathrm{~cm}$ and successive height reduction (Figure 1).

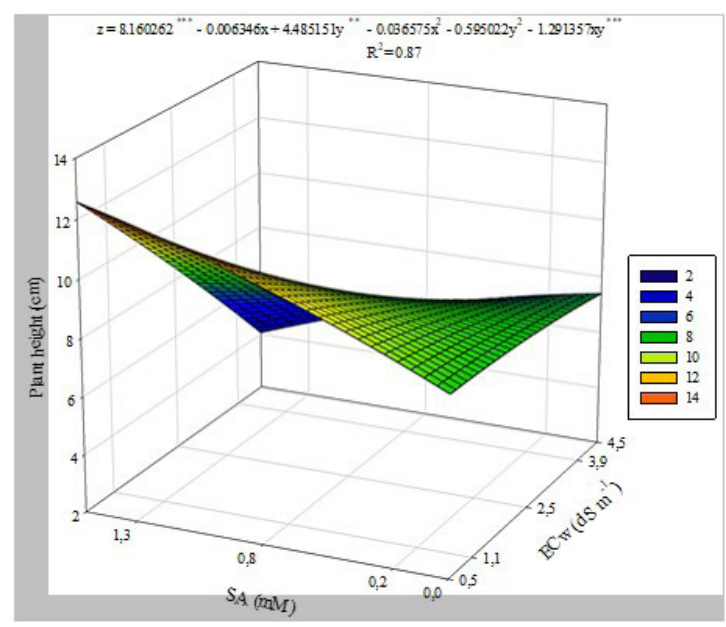

Figure 1. Plant height of eggplant seedlings as a function of salicylic acid concentrations (SA) and electrical conductivity in irrigation water $(\mathrm{ECW})\left({ }^{* * *},{ }^{* *}\right.$ significant at $0.01 \%$ and $1 \%$ of probability, respectively).
In the highest electrical conductivities of water (3.9 and $4.1 \mathrm{dS} \mathrm{m}^{-1}$ ), there was a decline of 29.57 and $45.02 \%$, in the respective salinities, in the range between 0 and $1.5 \mathrm{mM}$ of SA. Probably, the excess of salts without application of SA, as well as a high concentration of the acid associated with the highest saline levels, promoted a harmful effect on the growth of seedlings, since the continuous addition of water with high levels of soluble and toxic salts can cause water deficit, nutritional imbalance and toxicity by specific ions, interfering in the plant's growth (Parihar et al., 2015; Taiz et al., 2017). Similarly, reduced height in eggplant seedlings due to the increase in the electrical conductivity of irrigation water was observed by Oliveira et al. (2016) in the cultivars Comprida Roxa and Preta Comprida cultivars.

In the study by Almeida et al. (2019) with eggplant Embú without SA observed seedling height of approximately $7 \mathrm{~cm}$ in the ECW of $0.5 \mathrm{dS} \mathrm{m}^{-1}$ with successive reduction as the conductivity increased, it is noted in the present work that the use of SA $(1.2 \mathrm{mM})$ promoted a beneficial effect up to $2.5 \mathrm{dS} \mathrm{m}^{-1}$, with a height of $8.56 \mathrm{~cm}$ and, in the lowest conductivities, 0.5 and $1.1 \mathrm{dS} \mathrm{m}^{-1}$ achieved a height of 12.56 and $11.36 \mathrm{~cm}$, respectively at the $1.5 \mathrm{mM}$ of SA concentration.

With the use of SA, the activities of antioxidant enzymes, such as superoxide dismutase, catalase, and peroxidase are incremented (Dutra et al., 2017), these enzymatic components act through oxidative stress prevention mechanisms requiring energy expenditure, which decreases plant growth, thus, the acid can attenuate the deleterious effect of salinity to a certain concentration and salinity in the water, since excessive doses reduced growth (Jayakannan et al., 2015; Jini and Joseph, 2017). Fariduddin et al. (2018) observed an increase in tomato morphology in saline conditions using SA.

Regarding the number of leaves (Figure 2), a quadratic effect was observed in the ECW $1.1 \mathrm{dS} \mathrm{m}^{-1}$ at the concentration of $0.9 \mathrm{mM}$ of SA, equivalent to approximately 6 leaves, with declines from these levels. There was a

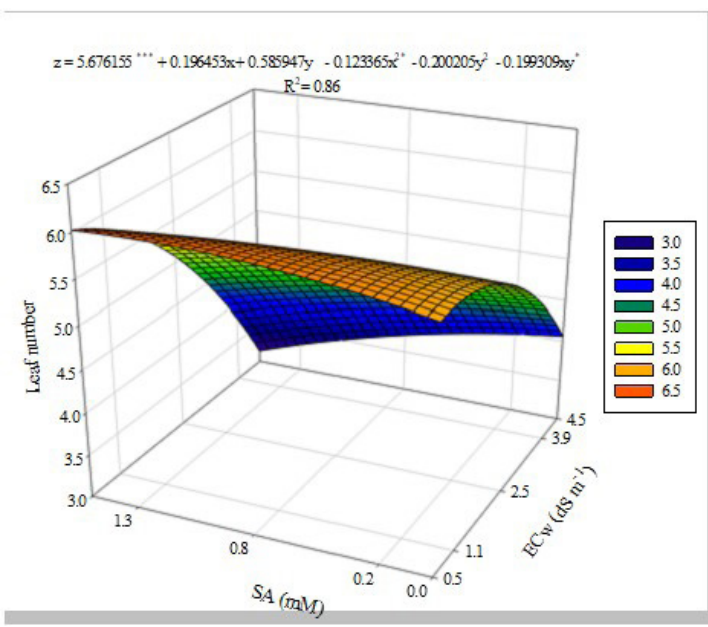

Figure 2. Number of eggplant leaves as a function of salicylic acid concentrations (SA) and electrical conductivity in irrigation water $(\mathrm{ECW})\left({ }^{* * *},{ }^{* *}\right.$ significant at $0.01 \%$ and $1 \%$ of probability, respectively). 
decreasing linear behavior from $6.02\left(0.5 \mathrm{dS} \mathrm{m}^{-1}\right)$ to 3.14 leaves $\left(4.5 \mathrm{dS} \mathrm{m}^{-1}\right)$ at the concentration of $1.5 \mathrm{mM}$ of SA.

SA plays important roles in physiological metabolism, including photosynthesis, nitrogen metabolism, antioxidant defense system, and plant-water relationships under stress conditions, however, in low concentration these functions are induced and in high inhibited, interfering with plants growth (Khan et al., 2015). Justifying the greater number of leaves up to $0.9 \mathrm{mM}$ of SA in the conductivity of $1.1 \mathrm{dS} \mathrm{m}^{-1}$ and the more marked reduction in the higher concentration of acid due to the increase in saline levels. Raghami et al. (2016) also found a beneficial effect on the number of leaves of eggplant seedlings using SA under salt stress.

As for the leaf area, a higher value $\left(740.37 \mathrm{~cm}^{2}\right)$ was observed in the higher concentration of SA and less electrical conductivity of the water (Figure 3 ). It was also found that there was an increasing linear behavior due to the application of SA up to $1.5 \mathrm{mM}$ and electrical conductivity up to $2.5 \mathrm{dS} \mathrm{m}^{-1}$, where it increased 65.73; 54.26 and $11.90 \%$ in the leaf area in the respective conductivities $0.5,1.1$ and $2.5 \mathrm{dS} \mathrm{m}^{-1}$.

The highest saline levels in the water drastically affected the leaf area of the seedlings, with declines of $50.01 \%$ (3.9 $\mathrm{dS} \mathrm{m}^{-1}$ ) and $78.33 \%\left(4.5 \mathrm{dS} \mathrm{m}^{-1}\right)$ despite the application of SA (Figure 3). Eggplant is considered as a salinity sensitive crop, with a threshold salinity of $1.5 \mathrm{dS} \mathrm{m}^{-1}$ (Ünlünkara et al., 2010). Therefore, the use of SA promoted mitigation up to $2.5 \mathrm{dS} \mathrm{m} \mathrm{m}^{-1}$, since its increased leaf area. However, higher concentrations of salts, even with the use of acid, may have caused phytotoxicity, probably because of the sensitivity in the seedling phase, and there is no mitigation of the effect of stress in these conditions.

By analyzing the electrolyte leakage of the electrolyte in the leaves of eggplant seedlings (Figure 4), it was found that it was higher in the seedling with a concentration of $4.5 \mathrm{dS} \mathrm{m}^{-1}$ (90.46\%) and without SA. The use of SA reduced the harmful effect of salt on the degradation of cell membranes, it can be inferred that even in the highest salt concentration the increase in acid reduced the percentage of damage. It was also notable that up to $3.9 \mathrm{dS} \mathrm{m} \mathrm{m}^{-1}$ the overflow remained stable with the use of the SA.

This increase of cell extrusion in saline conditions occurs due to phytotoxicity due to excess of $\mathrm{Na}^{+}$and $\mathrm{Cl}^{-}$in the leaf tissue, the accumulation of these ions promotes a change in the membrane composition, causing them to rupture (Ferraz et al., 2015). SA, in addition to signaling antioxidant genes and proteins under salinity conditions, can lead to a greater accumulation of ions responsible for the osmoregulation and structure of membranes, such as $\mathrm{K}^{+}$and $\mathrm{Ca}^{+2}$, and decrease the concentration of toxic ions $\mathrm{Na}^{+}$and $\mathrm{Cl}^{-}$. This may explain a reduction in leakage compared to the treatments absent of the SA application (Pirasteh-Anosheh et al., 2016). In a study with eggplant under saline and SA concentrations, it was reported that the leaf cell membrane structure under salt stress and SA suffered more damage in the higher salt concentration and that the use of acid reduced the damage compared to the absent treatment (Rajeshwari and Bhuvaneshwari, 2017).

The relative water content increased up to $1 \mathrm{mM}$ of SA at all saline levels, with a relative content of 77.35 , $69.01,51.64,37.23$, and $31.96 \%$ in the respective water conductivities $0.5,1.1,2.5,3.9$, and $4.5 \mathrm{dS} \mathrm{m}^{-1}$ (Figure 5).

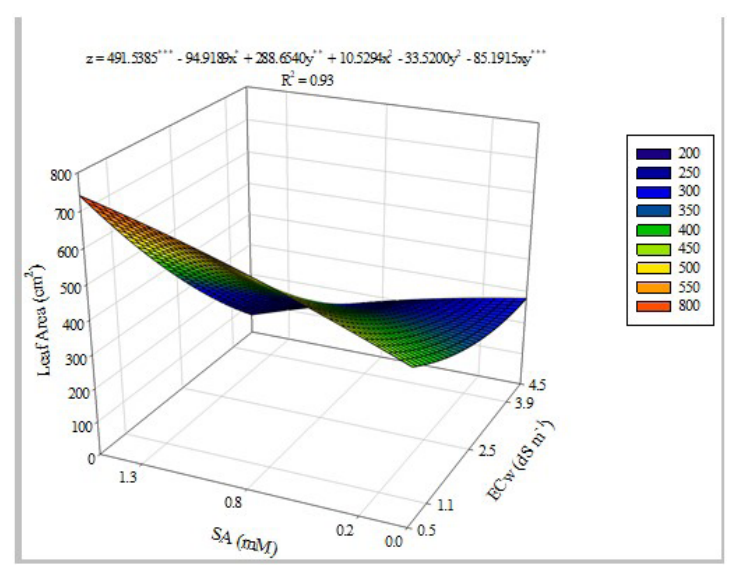

Figure 3. Eggplant leaf area as a function of salicylic acid concentrations (SA) and electrical conductivity in irrigation water $(\mathrm{ECW})\left({ }^{* * *},{ }^{* *}\right.$ significant at $0.01 \%$ and $1 \%$ of probability, respectively).

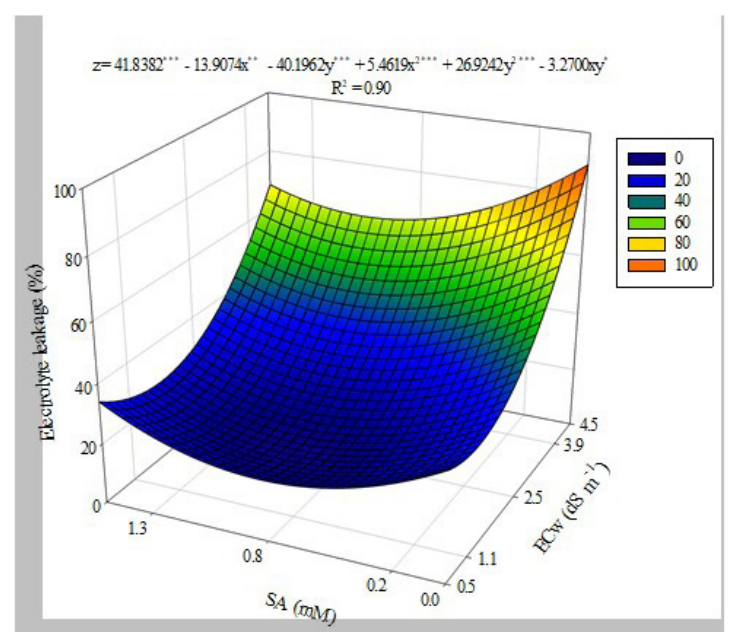

Figure 4. Eggplant electrolytes leakage as a function of salicylic acid concentrations (SA) and electrical conductivity in irrigation water $(\mathrm{ECW}){ }^{* * *},{ }^{* *}$ significant at $0.01 \%$ and $1 \%$ of probability, respectively).

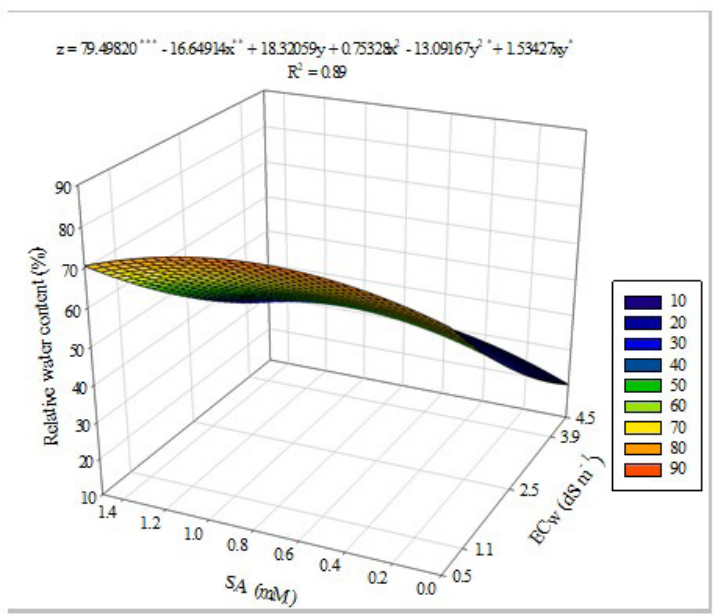

Figure 5. Relative eggplant water content as a function of salicylic acid concentrations (SA) and electrical conductivity in irrigation water $(\mathrm{ECW})\left({ }^{* * *},{ }^{* *}\right.$ significant at $0.01 \%$ and $1 \%$ of probability, respectively). 


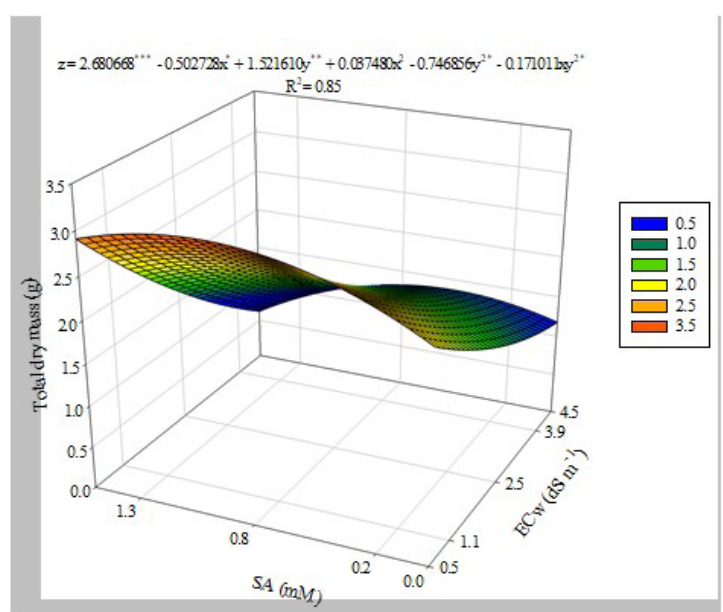

Figure 6. Total eggplant dry mass as a function of salicylic acid concentrations (SA) and electrical conductivity in irrigation water $(\mathrm{ECW}){ }^{* * *},{ }^{* *}$ significant at $0.01 \%$ and $1 \%$ of probability, respectively).

Daily irrigation with saline water causes less leaf water potential, due to the greater difficulty in removing water from the substrate, due to the excess of salts in the root zone (Acosta-Motos et al., 2017).

The effect of SA can be explained due to its ability to mitigate oxidative, osmotic, and ionic stress, increasing the concentrations of organic solutes for osmoregulation in plants, in addition to increasing the number of stomata, consequently maintaining the turgor in the leaf cells (Cárcamo et al., 2012; Farhangi-Abriz and GhassemiGolezani, 2018). In pepper culture, under salinity and SA, treatments of SA showed an increase in the relative water content and explain this fact related to the role of SA in the accumulation of compatible osmolytes, such as proline, in plants submitted to salinity stress (Amirinejad et al., 2017).

The accumulation of dry mass in eggplant seedlings decreased as a function of ECW, with a loss of $51.72 \%$ in the range between 0.5 to $4.5 \mathrm{dS} \mathrm{m}^{-1}$ in the absence of SA (Figure 6). With the application of SA, the reduction in total dry mass was lower, by observing a quadratic effect with an increase of up to $1.0 \mathrm{mM}$ in ECw $\left(0.5\right.$ to $\left.2.5 \mathrm{dS} \mathrm{m}^{-1}\right)$ and $0.5 \mathrm{mM}$ in the electrical conductivities of water above $2.5 \mathrm{dS} \mathrm{m} \mathrm{m}^{-1}$. Salicylic acid improved Root/Shoot in plants, balancing the distribution of reserves for growth (Pereira et al., 2021). Similar results were also found by Jan et al. (2016) when evaluating eggplant seedlings under saline stress using ascorbic acid.

In conclusion, increased salinity in water reduced growth in the absence of SA. The use of SA to a concentration of $1.0 \mathrm{mM}$ mitigated the deleterious effect of salinity on seedling growth up to $2.5 \mathrm{dS} \mathrm{m} \mathrm{m}^{-1}$.

\section{Acknowledgements}

The authors thank the Coordenação de Aperfeiçoamento de Pessoal de Nível Superior (CAPES) for their financial assistance in conducting the experiment. The Federal University of Paraiba on behalf of the Laboratory of Plant Ecology for infrastructure for research.

\section{References}

ACOSTA-MOTOS, J.R., ORTUÑO, M.F., BERNAL-VICENTE, A., DIAZVIVANCOS, P., SANCHEZ-BLANCO, M.J. and HERNANDEZ, J.A., 2017. Plant responses to salt stress: adaptive mechanisms. Agronomy, vol. 7, no. 1, pp. 18. http://dx.doi.org/10.3390/ agronomy7010018.

ALMEIDA, C.A.C., REIS, L.S., MELO JUNIOR, L.M., PACHECO, A.G., SILVA, T.S.S. and DIAS, M.S., 2019. Germinação e crescimento inicial de berinjela (Solanum melongena L.) em diferentes substratos e níveis de salinidade. Revista Ambientale, vol. 11, no. 7, pp. 88-101. http://dx.doi.org/10.34032/ambientale.v11i1.225.

AMIRINEJAD, A.A., SAYYARI, M., GHANBARI, F. and KORDI, S., 2017. Salicylic acid improves salinity-alkalinity tolerance in pepper (Capsicum annuum L.). Advances in Horticultural Science, vol. 31, no. 3, pp. 157-163.

ASENSI-FABADO, M. and MUNNÉ-BOSCH, S., 2011. The aba3-1 mutant of Arabidopsis thaliana withstands moderate doses of salt stress by modulating leaf growth and salicylic acid levels. Journal of Plant Growth Regulation, vol. 30, no. 4, pp. 456-466. http://dx.doi.org/10.1007/s00344-011-9208-x.

BALLIU, A., MARŠIĆ, N.K. and GRUDA, N., 2017. Seedling production. In: W. BAUDOIN, A. NERSISYAN, A. SHAMILOV, D. HODDER and S. GUITERREZ, eds. Good agricultural practices for greenhouse vegetable production in the South East European countries: principles for sustainable intensification of smallholder. Roma: FAO, pp. 189-206.

BERNARDO, S., SOARES, A.A. and MANTOVANI, E.C., 2006. Manual de irrigação. 8th ed. Viçosa: UFV.

CÁRCAMO, H.J., BUSTOS, R.M., FERNÁNDEZ, F.E. and BASTÍAS, E.I., 2012. Mitigating effect of salicylic acid in the anatomy of the leaf of Zea mays L. lluteño ecotype from the Lluta Valley (AricaChile) under $\mathrm{NaCl}$. Idesia, vol. 30, no. 3, pp. 55-63. http://dx.doi. org/10.4067/S0718-34292012000300007.

COSTA, A.A., PAIVA, E.P., TORRES, S.B., SOUZA NETA, M.L., PEREIRA, K.T.O., LEITE, M.S., SÁ, F.V.S. and BENEDITO, C.P., 2022. Osmoprotection in Salvia hispanica L. seeds under water stress attenuators. Brazilian Journal of Biology = Revista Brasileira de Biologia, vol. 82, pp. e233547. http://dx.doi.org/10.1590/15196984.233547. PMid:34105656.

DIAS, N.S., BLANCO, F.F., SOUZA, E.R., FERREIRA, J.F.S., SOUSA NETO, O.N. and QUEIROZ, I.S.R., 2016. Efeitos dos sais na planta e tolerância das culturas à salinidade. In: H.R. GHEYI, N.S. DIAS, C.F. LACERDA, E. GOMES FILHO, eds. Manejo da salinidade na agricultura: estudos básicos e aplicados. Fortaleza: INCTSal.

DUTRA, W.F., MELO, A.S., SUASSUNA, J.F., DUTRA, A.F., SILVA, D.C. and MAIA, J.M., 2017. Antioxidative responses of cowpea cultivars to water deficit and salicylic acid treatment. Agronomy Journal, vol. 109, no. 3, pp. 895-905. http://dx.doi.org/10.2134/ agronj2015.0519.

Empresa Brasileira de Pesquisa Agropecuária - EMBRAPA, 2006. Sistema brasileiro de classificação de solos. 5. ed., Brasília: Embrapa, 353 p.

FARHANGI-ABRIZ, S. and GHASSEMI-GOLEZANI, K., 2018. How can salicylic acid and jasmonic acid mitigate salt toxicity in soybean plants? Ecotoxicology and Environmental Safety, vol. 147, pp. 1010-1016. http://dx.doi.org/10.1016/j.ecoenv.2017.09.070. PMid:29976003.

FARIDUDDIN, Q., KHAN, T.A., YUSUF, M., AAFAQEE, S.T. and KHALIL, R.R.A.E., 2018. Ameliorative role of salicylic acid and spermidine in the presence of excess salt in Lycopersicon esculentum. Photosynthetica, vol. 56, no. 3, pp. 750-762. http://dx.doi. org/10.1007/s11099-017-0727-y. 
FERNANDES, C.S., SÁ, F.V.S., FERREIRA NETO, M., DIAS, N.S., REGES, L.B.L., GHEYI, H.R., PAIVA, E.P., SILVA, A.A. and MELO, A.S., 2022. Ionic homeostasis, biochemical components and yield of Italian zucchini under nitrogen forms and salt stress. Brazilian Journal of Biology = Revista Brasileira de Biologia, vol. 82, pp. e233567. http://dx.doi.org/10.1590/1519-6984.233567. PMid:34105657.

FERRAZ, R.L.S., MAGALHÃES, I.D., BELTRÃO, N.E.M., MELO, A.S., BRITO NETO, J.F. and ROCHA, M.S., 2015. Photosynthetic pigments, cell extrusion and relative leaf water content of the castor bean under silicon and salinity. Revista Brasileira de Engenharia Agrícola e Ambiental, vol. 19, no. 9, pp. 841-848. http://dx.doi. org/10.1590/1807-1929/agriambi.v19n9p841-848.

FERREIRA, E.B., CAVALCANTI, P.P. and NOGUEIRA, D.A. 2018 [viewed 24 December 2021]. ExpDes.pt: pacote experimental designs (portuguese): $R$ package version 1.2.0 [online]. Available from: https://CRAN.R-project.org/package=ExpDes.pt

HASANUZZAMAN, M., BHUYAN, M.H.M.B., ANNE, T.I., PARVIN, K., NAHAR, K., MAAHMUD, J.A. and FUJITA, M., 2019. Regulation of Ascorbate-Glutathione Pathway in Mitigating Oxidative Damage in Plants under Abiotic Stress. Antioxidants, vol. 8, no. 9, pp. 384. http://dx.doi.org/10.3390/antiox8090384.

HINNAH, F.D., HELDWEIN, A.B., MALDANER, I.C., LOOSE, L.H., LUCAS, D.D.P. and BORTOLUZZI, M.P., 2014. Estimation of eggplant leaf area from leaf dimensions. Bragantia, vol. 73, no. 3, pp. 213-218. http://dx.doi.org/10.1590/1678-4499.0083.

IRIGOYEN, J.J., EMERICH, D.W. and SÁNCHEZ-DÍAZ, M., 1992. Water stress induced changes in concentrations of proline and total soluble sugars in nodulated alfalfa (Medicago sativa) plants. Physiologia Plantarum, vol. 84, no. 1, pp. 67-72. http://dx.doi. org/10.1111/j.1399-3054.1992.tb08766.x.

JAN, S., HAMAYUN, M., WALI, S., BIBI, A., GUL, H. and RAHIM, F., 2016. Foliar application of ascorbic acid mitigates sodium chloride Induced stress in eggplant (Solanum melongena L.). Pakistan Journal of Botany, vol. 48, no. 3, pp. 869-876.

JAYAKANNAN, M., BOSE, J., BABOURINA, O., RENGEL, Z. and SHABALA, S., 2015. Salicylic acid in plant salinity stress signaling and tolerance. Plant Growth Regulation, vol. 76, no. 1, pp. 25-40. http://dx.doi.org/10.1007/s10725-015-0028-z.

JINI, D. and JOSEPH, B., 2017. Physiological mechanism of salicylic acid for alleviation of salt stress in rice. Rice Science, vol. 24, no. 2, pp. 97-108. http://dx.doi.org/10.1016/j.rsci.2016.07.007.

KAYA, C., ASHRAF, M., ALYEMENI, M.N. and AHMAD, P., 2020. The role of endogenous nitric oxide in salicylic acid-induced upregulation of ascorbate-glutathione cycle involved in salinity tolerance of pepper (Capsicum annuum L.) plants. Plant Physiology and Biochemistry, vol. 147, pp. 10-20. http://dx.doi.org/10.1016/j. plaphy.2019.11.040. PMid:31837556.

KHAN, M.I., FATMA, M., PER, T.S., ANJUM, N.A. and KHAN, N.A., 2015. Salicylic acid-induced abiotic stress tolerance and underlying mechanisms in plants. Frontiers in Plant Science, vol. 6, pp. 462. http://dx.doi.org/10.3389/fpls.2015.00462. PMid:26175738.

KWON, Y.I., APOSTOLIDIS, E. and SHETTY, K., 2008. In vitro studies of eggplant (Solanum melongena) phenolics as inhibitors of key enzymes relevant for type 2 diabetes and hypertension. Bioresource Technology, vol. 99, no. 8, pp. 2981-2988. http:// dx.doi.org/10.1016/j.biortech.2007.06.035. PMid:17706416.

LIMA, A.L.A., OLIVEIRA, F.A., ALVES, R.C., LINHARES, P.S.F., MEDEIROS, A.M. and BEZERRA, F.M.S., 2015. Tolerância da berinjela à salinidade da água de irrigação. Revista agro@mbiente on-line, vol. 9, no. 1, pp. 27-34. http://dx.doi.org/10.5327/Z19828470201500012202.

LUTTS, S., KINET, J. and BOUHARMONT, J., 1996. NaCl induced senescence in leaves of rice (Oryza sativa) cultivars differing in salinity resistance. Annals of Botany, vol. 78, no. 3, pp. 389-398. http://dx.doi.org/10.1006/anbo.1996.0134.

MEDEIROS, J.F., 1992. Qualidade da água de irrigação e evolução da salinidade nas propriedades assistidas pelo "GAT" nos Estado do $R N$, PB e CE. Campina Grande: Universidade Federal de Campina Grande, 172 p. Dissertação de Mestrado em Engenharia Agrícola.

MENEGHELLI, L.A.M., MONACO, P.A.V.L., HADDADE, I.R., MENEGHELLI, C.M. and ALMEIDA, K.M., 2017. Agricultural residues as a substrate in the production of eggplant seedlings. Horticultura Brasileira, vol. 35, no. 4, pp. 527-533. http://dx.doi. org/10.1590/s0102-053620170409.

MIMOUNI, H., WASTI, S., MANAA, A., GHARBI, E., CHALH, A., VANDOORNE, B., LUTTS, S. and AHMED, H.B., 2016. Does salicylic acid (SA) improve tolerance to salt stress in plants? A study of SA effects on tomato plant growth, water dynamics, photosynthesis, and biochemical parameters. OMICS: A Journal of Integrative Biology, vol. 20, no. 3, pp. 180-190. http://dx.doi. org/10.1089/omi.2015.0161. PMid:26909467.

MUNNS, R. and TESTER, M., 2008. Mechanisms of salinity tolerance. Annual Review of Plant Biology, vol. 59, no. 1, pp. 651-681. http://dx.doi.org/10.1146/annurev.arplant.59.032607.092911. PMid: 18444910.

NÓBREGA, J.S., BRUNO, R.L.A., FIGUEIREDO, F.R.A., SILVA, T.I., FÁTIMA, R.T., FERREIRA, J.T.A., SILVA, R.T. and CAVALCANTE, L.F., 2020. Growth and fluorescence rates of Mesosphaerum suaveolens (L.) Kuntze under saline stress and salicylic acid doses. Agrária, vol. 15, no. 3, pp. e7012. http://dx.doi.org/10.5039/ agraria.v15i3a7012.

OLIVEIRA, F.S., SÁ, F.V.S., SOUTO, L.S., PAIVA, E.P., OLIVEIRA, F.A., ARAÚJO, E.B.G., OLIVEIRA NETO, H.T. and MESQUITA, E.F., 2016. Seedling of development and tolerance of eggplant cultivars under saline stress. African Journal of Agricultural Research, vol. 11, no. 26, pp. 2310-2315. http://dx.doi.org/10.5897/ AJAR2016.11245.

PARIHAR, P., SINGH, S., SINGH, R., SINGH, V.P. and PRASAD, S.M., 2015. Effect of salinity stress on plants and its tolerance strategies: a review. Environmental Science and Pollution Research International, vol. 22, no. 6, pp. 4056-4075. http:// dx.doi.org/10.1007/s11356-014-3739-1. PMid:25398215.

PEREIRA, K.T.O., SÁ, F.V.S., TORRES, S.B., PAIVA, E.P., ALVES, T.R.C. and OLIVEIRA, R.R., 2021. Exogenous application of organic acids in maize seedlings under salt stress. Brazilian Journal of Biology = Revista Brasileira de Biologia, vol. 84, pp. e250727. http://dx.doi.org/10.1590/1519-6984.250727. PMid:34705951.

PIRASTEH-ANOSHEH, H., EMAM, Y., ROUSTA, M.J. and ASHRAF, M., 2016. Salicylic acid induced salinity tolerance through manipulation of ion distribution rather than ion accumulation. Journal of Plant Growth Regulation, vol. 36, no. 1, pp. 227-239. http://dx.doi.org/10.1007/s00344-016-9633-y.

RAFIQUE, N., RAZA, S.H., QASIM, M. and IQBAL, N., 2011. Pre-sowing application of ascorbic acid and salicylic acid to seed of pumpkin and seedling response to salt. Pakistan Journal of Botany, vol. 43, no. 6, pp. 2677-2682.

RAGHAMI, M., ESTAJI, A., BAGHERI, V. and ARYAKIA, E., 2016. Effect of salinity stress and salicylic acid on some morphophysiological characteristics of eggplant (Solanum melongena var. Taki) in soilless culture. Majallah-i Ulum va Funun-i Kisht/Ha-Yi Gulkhanah/I, vol. 7, no. 27, pp. 77-87. http://dx.doi.org/10.18869/ acadpub.ejgcst.7.27.77.

RAJESHWARI, V. and BHUVANESHWARI, V., 2017. Enhancing salinity tolerance in brinjal plants by application of salicylic acid. Journal of Plant Sciences, vol. 12, no. 1, pp. 46-51. http:// dx.doi.org/10.3923/jps.2017.46.51. 
RHOADES, J.D., KANDIAH, A. and MASHALI, A.M., 1992. Uso de águas salinas para produção agrícola. Tradução de Gheyi, H. R., Sousa J. R. and Queiroz J. E. Campina Grande: UFPB.

RIBEIRO, J.E.S., SOUSA, L.V., SILVA, T.I., NÓBREGA, J.S., FIGUEIREDO, F.R.A., BRUNO, R.L.A., DIAS, T.J. and ALBUQUERQUE, M.B., 2020. Citrullus lanatus morphophysiological responses to the combination of salicylic acid and salinity stress. Agrária, vol. 15 , no. 1, pp. 1-13. http://dx.doi.org/10.5039/agraria.v15i1a6638.

SANTOS, J.M.A.P., OLIVEIRA, F.A., MEDEIROS, J.F., TARGINO, A.J., COSTA, L.P. and SANTOS, S.T., 2018. Saline stress and potassium/ calcium ratio in fertigated eggplant. Revista Brasileira de Engenharia Agrícola e Ambiental, vol. 22, no. 11, pp. 770-775. http://dx.doi.org/10.1590/1807-1929/agriambi.v22n11p770-775.

SILVA, T.I., GONÇALVES, A.C.M., MELO FILHO, J.S., ALVES, W.S., BASILIO, A.G.S., FIGUEIREDO, F.R.A., DIAS, T.J. and BLANK, A.F., 2019. Echophysiological aspects of Ocimum basilicum under saline stress and salicylic acid. Agrária, vol. 14, no. 2, pp. e5633. http://dx.doi.org/10.5039/agraria.v14i2a5633.

TAIZ, L., ZEIGER, E., MOLLER, I.M. and MURPHY, A., 2017. Fisiologia e desenvolvimento vegetal. 6.ed. Porto Alegre: Artmed.

TEKINDAL, M.A., BAYRAK, H., ÖZKAYA, B. and YAVUZ, Y., 2014. Second-order response surface method: factorial experiments an alternative method in the field of agronomy. Turkish Journal of Field Crops, vol. 19, no. 1, pp. 35-45. http://dx.doi. org/10.17557/tjfc.78787.

ÜNLÜNKARA, A., KURUNÇ, A., KESMEZ, G.D., YURTSEVEN, E. and SUAREZ, D.L., 2010. Effects of salinity on eggplant (Solanum melongena L.) growth and evapotranspiration. Irrigation and Drainage, vol. 59, pp. 203-214. http://dx.doi.org/10.1002/ird.453.

ZÖRB, C., GEILFUS, C.M. and DIETZ, K.J., 2019. Salinity and crop yield. Plant Biology, vol. 21, no. S1, suppl. 1, pp. 31-38. http:// dx.doi.org/10.1111/plb.12884. PMid:30059606. 